\title{
Efficiency of box-traps and leg-hold traps with several bait types for capturing small carnivores (Mammalia) in a disturbed area of Southeastern Brazil
}

Fernanda Michalski ${ }^{1}$, Peter G. Crawshaw JR. ${ }^{2}$, Tadeu G. de Oliveira ${ }^{3}$ \& Marta E. Fabián ${ }^{4}$

1 Instituto Pró-Carnívoros \& University of East Anglia, School of Environmental Sciences, NR4 7TJ, Norwich, UK; fmichalski@procarnivoros.org.br. Fax 44(1603)591327

2 Centro Nacional de Pesquisa para a Conservação de Predadores Naturais (CENAP/IBAMA), C.P. 79, 95400-000, São Francisco de Paula, RS, Brasil; pcrawshaw@uol.com.br

3 Departamento de Biologia,Universidade Estadual do Maranhão, C.P. 09, São Luis, MA, 65055-098, Brasil \& Instituto Pró-Carnívoros; tadeu4@yahoo.com

4 Instituto de Biociências, Departamento de Zoologia, Universidade Federal do Rio Grande do Sul (UFRGS), Campus do Vale, Prédio 43435, Av. Bento Gonçalves 9500, 91501-970, Porto Alegre, RS, Brasil; mfabian@vortex.ufrgs.br

Received 17-V-2004. Corrected 16-I-2006. Accepted 19-X-2006.

\begin{abstract}
Capturing small carnivores is often necessary for obtaining key ecological data. We compared the efficiency of box and leg-hold traps, using live and dead bait, to capture six carnivore species (Herpailurus yagouaroundi (É. Geoffroyi, 1803), Leopardus tigrinus (Schreber, 1775), Nasua nasua (Linnaeus, 1766), Cerdocyon thous (Linnaeus, 1766), Eira barbara (Linnaeus, 1758), and Galictis cuja (Molina, 1782)). The use of leg-hold traps significantly increased the capture rate of carnivores $(5.77 \%)$ and non-target species (non-carnivores, $11.54 \%$ ). Dead bait significantly attracted more non-carnivores than carnivores and live bait was more efficient for capturing carnivores $(2.56 \%)$ than non-carnivores $(0.77 \%)$. Both box and leg-hold traps caused some minor injuries (swelling and claw loss). We provide recommendations for the ethical use of these trap and bait types. Rev. Biol. Trop. 55 (1): 315-320. Epub 2007 March. 31.
\end{abstract}

Key words: Atlantic forest, box-trap, leg-hold trap, capture success, mammals, small carnivores, non-carnivores, ethics.

Animal trapping is often necessary for the study of mammalian biology. Due to their secretive life style (Emmons and Feer 1997) capturing small carnivores is frequently required to collect information on many ecological parameters, such as activity patterns and home range size. However, captures can result in injuries to the animals and/or to personnel involved (Crawshaw 1997). Leg-hold traps, although considered by some as the most efficient method to capture wild carnivores are the most controversial due to the possibility of limb injuries (Olsen et al. 1986, Glass 1990). Modifications such as padding the jaws of the trap and the use of springs in the chains to reduce the negative effects of thrashing while the animal is in the trap can effectively reduce injuries (Balser 1965, Linhart et al. 1986, Onderka et al. 1990). In this case, leg-hold trap selectivity toward target species and their efficacy can make their use desirable (Turkovski et al. 1984). Type of bait is another factor influencing capture effort and success for the different species. Jones et al. (1996) mentioned the importance of live bait vocalization to attract carnivores to traps. For this and other reasons, live baits are frequently used to trap predators (e.g., Dietz 1984, Emmons 1988, Konecny 1989, Sunquist et al. 1989, Crawshaw 1995). In this paper, we report carnivore capture results 
from a radio-telemetry study using leg-hold and Tomahawk-type box-traps, with different combinations of dead and live bait.

\section{MATERIALS AND METHODS}

From August 1997 to July 1998, we accumulated a total of 736 trapnights (684 with box-trap, and 52 with leg-hold trap) to capture small carnivores at Ipanema National Forest $\left(23^{\circ} 25^{\prime} \mathrm{S}-23^{\circ} 17^{\prime} \mathrm{S}\right.$; $\left.47^{\circ} 35^{\prime} \mathrm{W}-47^{\circ} 40^{\prime} \mathrm{W}\right)$, São Paulo State, Brazil. This 5063 ha area comprises a mosaic of disturbed semideciduous Atlantic forest, secondary forest, grassland savanna, and Eucalyptus (L'Hér, 1789) plantation. The number of traps used per night varied between one and nine, with an average of 3.2. The period of each trapnight was $24 \mathrm{~h}$. The capture rate was measured as the total number of captures of each species divided by the number of trapnights with each type of trap or bait and expressed as a percentage. We used sardine or pieces of chicken as dead bait (345 trapnights), and live chickens and quails as live baits (391 trapnights). When using live baits, the back of the trap, where chickens and quails were kept were covered with plastic to protect against rain and wind, and food and drinking water were replaced every day. The back of the traps were also cleaned regularly. Live bait was vaccinated prior to exposure in the field. The box-traps $(70 \times 70 \times 130 \mathrm{~cm}$, height $\mathrm{x}$ width $\mathrm{x}$ length, respectively) and leg-hold traps (Victor ${ }^{\circledR}$ No. 1 soft-catch coil spring) were placed on or adjacent to trails. After 15 days in one area, the traps were moved to other sites. Traps were checked twice a day, early in the morning and late afternoon. We used the software Resampling Stats Excel, Inc. (Simon and Bruce 1991) to perform 1000 simulations within the range of our data (Table 2). Based on the normally distributed resampled data, we calculated a t test (two way sample) between the means of capture rate within different types of traps and baits. We also performed a nonparametric Chi-square tests (Zar 1999) based on our crude data.

\section{RESULTS}

Sixteen carnivores (including three recaptures) and 24 non-carnivores were captured during the study period. Carnivores included two felids, jaguarundi (Herpailurus yagouaroundi; $\mathrm{n}=5$ ) and little-spotted cat (Leopardus tigrinus; $\mathrm{n}=2$ ); one canid, the crab-eating fox (Cerdocyon thous; $\mathrm{n}=4$ ); one procyonid, the coati (Nasua nasua; $\mathrm{n}=2$ ) and two species of mustelids, tayra (Eira barbara; $\mathrm{n}=2$ ) and lesser grison (Galictis cuja; $\mathrm{n}=1$ ). Non-carnivore species captured were the opossum, Didelphis albiventris (Lund, 1840) $(\mathrm{n}=8)$ and Didelphis aurita (Wied-Neuwied, 1826) $(\mathrm{n}=11)$, the six-banded armadillo, Euphractus sexcinctus (Linnaeus, 1758) $(\mathrm{n}=3)$, and the tegu lizard, Tupinambis merianae (Duméril \& Bibron, 1839) $(\mathrm{n}=2)$ (Table 1).

The overall capture rate for carnivores, using both types of trap was $2.2 \%$, or 46 trapnights necessary to capture one carnivore. The capture rate using box-traps was $2.63 \%$ and $1.90 \%$ for non-carnivores and carnivores, respectively. The use of leg-hold traps increased the capture rate for non-carnivores to $11.53 \%$ and to $5.77 \%$ for carnivores (Table 1).

We found a significant difference between the mean capture rate of non-carnivores and carnivores using box and leg-hold traps $(\mathrm{t}=$ $-57.26, \mathrm{df}=999, \mathrm{p}<0.001 ; \mathrm{t}=-37.56, \mathrm{df}=999$, $\mathrm{p}<0.001$, respectively) (Table 2 ). The use of leg-hold traps significantly increased the capture rate for carnivores and non-carnivores together when compared to box-traps $\left(\chi^{2}=\right.$ 13.73; $\mathrm{df}=1 ; \mathrm{p}<0.001)$. Among all animals captured $(n=40)$, only 5 suffered injuries from the traps (Table 1).

The use of live bait in our study led to a higher carnivore capture $(n=10)$, whereas the use of dead bait attracted more non-carnivore species $(n=21)\left(\chi^{2}=8.38 ; d f=1 ; p<0.01\right)$. The mean capture rate of non-carnivores between these two types of baits differed significantly $(\mathrm{t}=159.05, \mathrm{df}=999, \mathrm{p}<0.001)$ (Table 2). The same pattern was observed between the mean capture rates of carnivores and the different baits $(\mathrm{t}=-202.43, \mathrm{df}=999, \mathrm{p}<0.001)($ Table 
TABLE 1

Capture rate (\%) according to the type of trap, number of animals injured, and type of bait used at Ipanema National Forest, São Paulo, Brazil. August 1997 - July 1998

Type of Trap

Species

\section{NON-CARNIVORES}

Didelphis albiventris

Didelphis aurita

Euphractus sexcinctus

Tupinambis merianae

Total

CARNIVORES

Herpailurus yagouaroundi

Leopardus tigrinus

Nasua nasua

Cerdocyon thous

Eira barbara

Galictis cuja

Total

\begin{abstract}
Box-trap
\end{abstract}
Leg-hold

Injuries

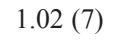

$1.02(7)$

0.44 (3)

0.15 (1)

2.63 (18)

$0.73(5)$
$0.29(2)$
$0.29(2)$
$0.29(2)$
$0.15(1)$
$0.15(1)$

Numbers in brackets correspond to the number of captures

$\begin{array}{cc}1.92(1) & 0 \\ 7.69(4) & 2 \\ -(0) & 0 \\ 1.92(1) & 0 \\ 11.53(6) & 2\end{array}$

- (0)

$3.85(2)$

$1.92(1)$

- (0)

$5.77(3)$
Bait

Dead Live

$0.77(3)$

$0.87(3)$

0.58 (2)

$6.09(21)$

0.77 (3)

- (0)

- (0)

0.29 (1)

$0.26(1)$

$1.16(4)$

0.29 (1)

- (0)

$1.74(6)$

$2.57(10)$

2). The capture rate using dead bait was $6.09 \%$

\section{DISCUSSION}

for non-carnivores and $1.74 \%$ for carnivores. The use of live bait decreased the capture rate for non-carnivores to $0.77 \%$ and increased for carnivores to $2.57 \%$ (Table 1). Nevertheless, all captures of crab-eating foxes $(n=4)$, contrary to other carnivores occurred with dead bait.

Our results showed that the use of leg-hold traps increased the capture rate of carnivores and non-carnivores in the study area, differing from other studies that could not find any significant difference of capture efficiency

TABLE 2

Mean number of capture rate for carnivores and non-carnivores according to the type of trap, and bait used after 1000 resamplings based on our original data from Ipanema National Forest, São Paulo, Brazil. August 1997 - July 1998

Type of Trap

$$
\text { Group }
$$

Non-Carnivores

Carnivores
Box-trap

0.67 (0.65-0.68)

$0.32(0.31-0.32)$
Leg-hold

2.85 (2.77-2.94)

0.95 (0.91-0.98)
Type of Bait

Dead

Live

$0.29(0.28-0.30)$

$0.42(0.41-0.43)$

Data in brackets are the $95 \%$ confidence intervals. 
between box and leg-hold trap (Molsher 2001). The significantly higher capture rate of leg-hold traps in this study is possibly a consequence of the fact that these traps are more easily concealed and cannot be seen by the animals.

We were unable to test for differences in the occurrence of injuries caused by the different types of trap. However Crawshaw (1997) mentioned that even though box-traps are usually considered to cause fewer injuries, in his experience, an animal can suffer less injury in an appropriately padded and monitored soft-catch leg-hold than in a box-trap. In fact, all animals captured with leg-holds (including small non-carnivores) showed only minor injuries, usually temporary swelling. This was likely because the traps were checked twice daily. Crawshaw (1997) surmised that potential injury could be directly related with the time the animal remains in the trap, due to the interruption of blood circulation. Balser (1965) mentioned that the major injuries are caused when the animal tries to escape; some even chew part of their own limb (automutilation). This author also noted the importance of time spent in the trap combined with pressure of the trap, to produce serious damage to the animal. Englund (1982) mentioned that the severity and frequency of injuries in foxes, caused by leg-holds, could be considerably reduced by covering parts of the trap with plastic. The use of rubber padding on the jaws of the trap and coils on the chains of legholds also significantly reduced injuries to trapped animals (Linhart et al. 1986, Onderka et al. 1990).

Although often overlooked, box-traps can also cause injuries. In Ipanema National Forest, one crab-eating fox lost some claws from the front paw trying to escape from the trap, and one opossum had superficial injuries to its nose. The use of restraining traps has been assessed by the ISO Technical Committee and claw loss is in the lowest trauma category (ISO 10990-5 1999, Harris et al. 2005). Superficial (and minor) injuries to the nose are not uncommon for several species of carnivores and noncarnivores in the Neotropics. One of special concern is the breaking of the canines, from biting the bars or wire-mesh, which can potentially compromise the survival of the individual after release. Tooth injuries can also occur with the use of leg-hold traps. However, few injuries to canines or carnassial teeth were reported for wolves; most often, damage occurred to premolars (Kuehn et al. 1986).

Olsen et al. (1986) mentioned that leghold traps could probably cause more injuries to animals, especially to smaller ones than the targeted species. However, in our study, small non-target animals captured, like opossums (Didelphis aurita), showed just superficial injuries, mostly temporary swelling.

Box-traps of adequate size and material can be efficient to capture medium-sized carnivores, especially if baited appropriately. One of the advantages to the use of box-traps is the possibility to use live bait, which is difficult when leg-holds are chosen.

The increase of capture rate for carnivores using live bait in the present study was noticed by previous studies. Crawshaw (1995) mentioned that the use of dead bait favored the capture of non-carnivore species such as the opossum, while live baits were more selective towards trapping carnivores. Movement and vocalization of the bait likely act as strong attractants, eliciting predatory behavior on the part of carnivores (Jones et al. 1996). Greater success with the use of live bait has been reported for several carnivore species (Emmons 1988, Konecny 1989, Sunquist et al. 1989). Chickens have been the most frequently used live prey, but rats and quails have also been used. On the other hand, dead bait like chunks of chicken and meat have also been used for trapping carnivores (e.g., Sunquist et al. 1989, Crawshaw 1995, T. Oliveira, unpubl.). However, criticisms from international conventions on the ethical treatment of experimental subjects and general concern about the use of live bait have raised questions as to the scientific justification for their use. Based on our experiences, we suggest that the use of playbacks with chicken vocalization coupled with chicken scent (possibly from feathers or scats) could possibly replace the use of live bait. But 
further experiments in the field are required to test the efficiency of such artificial attractants.

Our finding that crab-eating foxes were captured only with dead bait, has also been noted elsewhere for this species (Crawshaw 1995). It probably occurred because crab-eating foxes are opportunistic hunters, eating small vertebrates, insects and other invertebrates, fruits and carrion whenever available (Brady 1979).

In summary, although leg-hold traps could increase significantly the capture rate, and require less effort to transport than box-traps (Jones et al. 1996), making them attractive to researchers their use must be cautioned. Some researchers recommend that leg-hold traps should be used only if continuous monitor could be conducted, minimizing the time the animal remains in the trap (R.L.Pitman, pers.com.). Checks at least twice a day must be conducted to minimize injuries to the animals trapped. Box-traps are also effective to capture small carnivores if baited properly.

\section{ACKNOWLEDGMENTS}

We are grateful for the financial support provided by CENAP/IBAMA, CAPES and Programa de Pós-Graduação em Biologia Animal (UFRGS - to F. Michalski). We also thank Paulo de Marco Jr., Adriano P. Paglia and Daniela Wetezel Gastal, for helping with the statistical analyses.

\section{RESUMEN}

La captura de pequeños carnívoros es una práctica común para obtener datos ecológicos. Comparamos la eficiencia de cepos (trampas acolchadas) y trampas tomahawk para capturar seis especies carnívoras (Herpailurus yagouaroundi (É. Geoffroyi, 1803), Leopardus tigrinus (Schreber, 1775), Nasua nasua (Linnaeus, 1766), Cerdocyon thous (Linnaeus, 1766), Eira barbara (Linnaeus, 1758), and Galictis cuja (Molina, 1782)), utilizando carnadas vivas y muertas. Con los cepos se incrementó significativamente la tasa de captura de carnívoros $(5.77 \%$ ) y otros mamíferos (no-carnívoros, 11.54\%). La carnada muerta atrajo significativamente mas no-carnívoros que carnívoros, mientras que con la carnada viva se capturaron más carnívoros ( $2.56 \%$ vs $0.77 \%$ no-carnívoros). Ambos tipos de trampas; cepos y tomahawk, causaron algunas pequeñas lastimaduras (inflamación y pérdida de garras). Hacemos algunas recomendaciones para el uso ético de este tipo de trampas y cebos.

Palabras chave: Bosque atlántico, trampas tomahawk, cepos, éxito de captura, mamíferos, pequeños carnívoros, no-carnívoros.

\section{REFERENCES}

Balser, D.S. 1965. Tranquilizer tabs for capturing wild carnivores. J. Wildl. Manage. 29: 438-442.

Brady, C.A. 1979. Observations on the behavior and ecology of the Crab-eating fox (Cerdocyon thous), p. 161-171. In J.F. Eisenberg (ed.). Vertebrate Ecology in the Northern Neotropics. Smithsonian Institution, Washington D.C., USA.

Crawshaw Jr., P.G. 1995. Comparative Ecology of ocelot (Felis pardalis) and jaguar (Panthera onca) in a protected subtropical forest in Brazil and Argentina. Ph. D. Thesis. University of Florida, Gainesville, Florida, USA. 190 p.

Crawshaw Jr., P.G. 1997. Recomendações para um Modelo de Pesquisa sobre Felídeos Neotropicais, p. 70-94. In C. Valladares-Padua, R.E. Bodmer \& L. Cullen Jr. (eds.). Manejo e Conservação de Vida Silvestre no Brasil. CNPQ \& Belém, PA, Sociedade Civil Mamirauá, Brasília, D.F.

Dietz, J.M. 1984. Ecology and social organization of the maned wolf (Chrysocyon brachyurus). Smithson. Contrib. Zool. 392: 1-51.

Emmons, L.H. 1988. A field study of ocelots in Peru. Rev. Ecol. Terre Vie. 43: 133-157.

Emmons, L. \& F. Feer. 1997. Neotropical Rainforest Mammals: a field guide. The University of Chicago, Chicago, Illinois. 318 p.

Englund, J. 1982. A comparison of injuries to leg-hold trapped and foot-snared red foxes. J. Wildl. Manage. 46: 1113-1117.

Glass, J.H. 1990. The Status of the Steel Trap in North America, p. 252-254. In L.R. Davis \& R.E. Marsh (eds.). Proceedings of the $14^{\text {th }}$ Vertebrate Pest Conference. University of California, Davis, California, USA.

Harris, S., C. Soulsburry \& G. Iossa. 2005. A scientific review on proposed humane trapping standards in 
Europe. 1. The ISO standards and 2. the European Commission proposal for a proposed Directive on humane trapping standard. International Fund for Animal Welfare and Eurogroup for Animal Welfare, Brussels, Belgium. 39 p.

ISO 10990-5. 1999. Animal (mammal) traps-Part 5: Methods for testing restraining traps. International Organization for Standardization: Geneva, Switzerland.

Jones, C., W.J. McShea, M.J. Conroy \& T.H. Kunz. 1996. Capturing Mammals, p.115-155. In D.E. Wilson, F.R Cole, J.D. Nichols, R. Rudran \& M.S. Foster (eds.). Measuring and Monitoring Biological Diversity. Standard Methods for Mammals. Smithsonian Institution, Washington DC, USA.

Konecny, M.J. 1989. Movement patterns and food habitats of four sympatric carnivore species in Belize, Central America, p. 243-264. In K.H. Redford \& J.F. Eisenberg (eds.). Advances in Neotropical Mammalogy. The Sandhill Crane, Gainesville, Florida, USA.

Kuehn, D.W., T.K. Fuller, L.D. Mech, W.J. Paul, S.H. Fritts \& W.E. Berg. 1986. Trap-related injuries to gray wolves in Minnesota. J. Wildl. Manage. 50: 90-91.

Linhart, S.B., G.J. Dasch, C.B. Male \& R.M. Engeman. 1986. Efficiency of unpadded steel foothold traps for capturing coyotes. Wildl. Soc. Bull. 14: 212-218.
Molsher, R.L. 2001. Trapping and demographics of feral cats (Felis catus) in central New South Wales. Wildl. Res. 28: 631-636.

Olsen, G.H., S.B. Linhart, R.A. Holmes, G.J. Dasch \& C.B. Male. 1986. Injuries to coyotes caught in padded and unpadded steel foothold traps. Wildl. Soc. Bull. 14: 219-223.

Onderka, D.K., D.L. Skinner \& A.W. Todd. 1990. Injuries to coyotes and other species caused by four models of footholding devices. Wildl. Soc. Bull. 18: 175-182.

Simon, J.L. \& Bruce, P. 1991. Resampling: A tool for everyday statistical work. Chance 4: 22-32.

Sunquist, M.E., F. Sunquist \& D.E. Daneke. 1989. Ecological separation in a Venezuelan Llanos Carnivore Community, p. 197-232. In K.H. Redford \& J.F. Eisenberg (eds.). Advances in Neotropical Mammalogy. The Sandhill Crane, Gainesville, Florida, USA.

Turkovski, F.J., A.R. Armistead \& S.B. Linhart. 1984. Selectivity and effectiveness of pan tension devices for coyote foothold traps. J. Wildl. Manage. 48: 700-708.

Zar, J. H. 1999. Biostatistical Analysis. Prentice-Hall, London. 929 p. 